Ročník XVII (2015), Číslo 2, s. 242-249/ Volume XVII (2015), Issue 2, pp. 242-249

(c) Mezinárodní politologický ústav / International Institute of Political Science

DOI: $10.5817 / C E P S R .2015 .2 .242$

\title{
Rodney G. Peffer: Marxizmus, morálka a sociálna spravodlivost'
}

Bratislava: Vydavatel'stvo spolku slovenských spisovatelov, 2014. Edícia Pohl'ady za horizont, zv. 15. 492 s., ISBN 978-80-8061-815-5. Preklad: Richard Cedzo, predslov: Luboš Blaha.

\section{MARIÁN SEKERÁK ${ }^{1}$}

„Toto je závažná, ostro vyargumentovaná a na kvalitnom výskume založená kniha, ktorá osvetluje mimoriadne diskutovanú problematiku a pokúša sa ponúknut' vlastný osobitný príspevok“, napísal o Pefferovej knihe krátko po jej vyjdení vo svojej recenznej glose Vincent Geoghegan (1991: 438). Táto monografia, vychádzajúca zo značnej časti z autorovej dizertácie, vyšla v anglickom origináli ako „Marxism, Morality, and Social Justice“ v Princeton University Press v roku 1990, teda krátko po revolučných udalostiach roku 1989 v strednej Európe. Po 24 rokoch od jej vydania prišiel na knižné pulty aj slovenský preklad, ktorý pripravil erudovaný prekladatel' filozofickej literatúry Richard Cedzo. Ten má už na svojom prekladatel'skom konte napríklad dve Rawlsove publikácie: „Spravodlivost' ako férovost““ a „Právo národov s Revidovanou ideou verejného rozumu“. Nielenže sa tým zapíña pomyselné biele miesto v prípade vedeckých publikácií venovaných analytickému marxizmu na slovenskom (a českom) knižnom trhu, ale odbornej verejnosti (lebo najmä na ňu je kniha svojím charakterom zacielená) je ponúknutá možnost' reflektovat' Pefferove závery vo svetle najnovšej politicko-filozofickej diskusie, zvlášt' z pozície príslušníkov štátov, o ktorých svojho času autor, vyučujúci na University of San Diego v Kalifornii, písal ako o „spoločnostiach štátneho socializmu“, príp. ako o postkapitalistických spoločnostiach, teda o takých spoločnostiach, ktoré už neboli formálne ani technicky kapitalistické, ale ani plne socialistické (a už vôbec nie komunistické v marxistickom chápanî, pretože u nich síce existovalo spoločenské vlastníctvo výrobných prostriedkov (ale nie nevyhnutne

\footnotetext{
${ }^{1}$ Interný doktorand, Inštitút politologických štúdií, Fakulta sociálnych vied, Univerzita Karlova, Praha / Institute of Political Studies, Faculty of Social Sciences, Charles University, Prague, Czech Republic. E-mail: marian.sekerak@gmail.com. Recenzia vychádza v rámci inštitucionálnej podpory IPS FSV UK v Prahe.
} 
zamestnanecká samospráva, teda ekonomická demokracia - s výnimkou vtedajšej Juhoslávie), avšak nie politická demokracia ako condicio sine qua non socializmu, teda neboli v nich zabezpečené základné l’udské a občianske práva a slobody.

A práve $\mathrm{v}$ tomto bode, v podstate na konci Pefferovej knihy, by sme mohli začat' naše uvažovanie o nej. Posledných necelých 20 strán monografie sa totiž zásadne líši od tých predchádzajúcich a týka sa navyše aj našej geografickej oblasti. Tieto posledné strany - a jeden z jej recenzentov, Arthur DiQuattro (1992: 617), píše, že „našt’astie len tieto posledné strany“ - sa môžu ponášat’ na niečo, čo sa javí ako „trockistická politická cesta“ (ibid.). Peffer ako presvedčený marxista tam totiž napríklad otvorene vyhlasuje, že „práve Spojené štáty americké majú obrovské výdavky na vojny, a tiež aktívne vojensky zasahujú po celom svete, a to v záujme ochrany (...) práva západnej kapitalistickej ekonomiky na disponovanie s priaznivými investičnými príležitost’ami“ (s. 431). Alebo na inom mieste tvrdí, že „[a]ntikapitalistické revolúcie v rozvojových krajinách sú (...) možno jediným účinným spôsobom, ako zabezpečit' právo na život pre všetkých l’udí“ (s. 434), prípadne že kapitalistické mocnosti „,priamo poverujú svoje vlastné tajné služby (napríklad CIA), aby manipulovali vol'by, rozvracali ekonomiky, páchali atentáty na nepohodlných protivníkov atd'." (ibid.). Z tohto dôvodu by sme podla autora knihy mali - ak predpokladáme platnost' marxistickej politickej teórie podporovat' tie „politické strany, ktoré sa otvorene hlásia k zrušeniu kapitalizmu“ (s. 442, kurzíva v orig.), prípadne ak máme problém nájst' takúto reformnú evolučnú cestu, musíme sa obrátit' k revolučným formám zmeny spoločenského poriadku.

Ak by Peffer ostal len pri týchto silných vyhláseniach, jeho kniha by zrejme vzbudila záujem konšpirátorov, bojovníkov proti americkej vojensko-ekonomickej hegemónii, alebo odporcov imperializmu (a dnes aj globalizácie), t’ažko však už politických filozofov. Tu len malá odbočka k zjavnému paradoxu: môžeme sa čudovat', prečo taký tvrdý kapitalistický režim zameraný na svoje vlastné udržanie a expanziu ako je v USA umožňoval svoju vlastnú kritiku, dovol’oval svojim oponentom a zároveň vlastným štátnym občanom vyzývat' $\mathrm{k}$ jeho revolučnému zvrhnutiu (realizovanému prinajmenšom $\mathrm{v}$ iných kapitalistických krajinách) a z pozície univerzitných pedagógov im láskavo poskytoval možnost' publikovat' ich názory $\mathrm{v}$ prestížnych akademických vydavatel'stvách... V každom prípade, odhliadnuc od týchto paradoxov a kontroverzných miest, najväčšia pridaná hodnota knihy spočíva kdesi inde. Vzhl'adom na mohutnost' problematiky a rozsiahlost' knihy (pozostávajúcej z 10 dlhých kapitol) ju môžeme koncentrovat' do dvoch bodov.

Prvým je snaha o empirické odôvodnenie názoru, podl’a ktorého Marxa nemožno objektívne nepokladat' za myslitel'a s vlastnou presvedčivou morálnou teóriou. „Hoci Marx nie je moralistom v zmysle, že káže morálku alebo predkladá priame morálne vyhlásenia (...), jeho myslenie je absolútne a dôkladne naplnené morálnymi súdmi a princípmi“" (s. 209). Tak, ako sa kedysi sv. Tomáš Akvinský pokúsil „pokrstit““ Aristotela, tak sa aj kalifornský filozof usiloval napasovat' 
Marxa do hávu morálnej teórie. Táto Pefferova snaha presvedčit' nás o existencii nejakej Marxovej morálnej teórie ústi do tvrdenia, že by sme ho mali považovat' za „zmiešaného deontológa“. V tomto prípade ide podl’a Peffera o teóriu správneho konania alebo záväzku, „ktorá presadzuje jeden alebo viacero typov mimomorálneho dobra - v Marxovom prípade slobody, l'udského spoločenstva a sebarealizácie - ale obsahuje v sebe myšlienku, že maximalizácia mimomorálneho dobra jednoducho nie je kritériom správneho konania“ (s. 98). Toto Pefferovo odhodlanie vykročit' novou cestou nazval už citovaný DiQuattro (1992: 617) „správnym smerom: preč od Hegela smerom ku Kantovi““.

Peffer tvrdí, že hoci v komunistickej spoločnosti, ako ju približne predstavil Marx, nebudú potrebné kategórie a pojmy práv, v socialistickej spoločnosti ako prechodovom štádiu je nevyhnutné aktívne operovat' s právami a slobodami. Ilustruje to na príklade pozitívnej slobody, teda slobody určovat' svoj vlastný život, ktorá, na základe analytickej rekonštrukcie Marxovho diela, pozostáva z (1) práva na rovnakú účast' na všetkých spoločenských rozhodovacích procesoch a (2) práva na rovnaký prístup k prostriedkom sebarealizácie (pozri s. 141-144). Aj preto Pefferov ideál, spoločnost' demokratického samosprávneho socializmu, musí spočívat' na týchto zásadách. A aby sme mohli povedat', že takáto spoločnost' je v súlade s Marxovou teóriou spravodlivosti - aj ked’ ju takto sám nepomenoval a s konceptom spravodlivosti nepracoval tak ako dnešní morálni a sociálni filozofi -, nemôžeme nepopriet', že Marx predstavil nejakú, aj ked' nie celkom koherentnú, morálnu teóriu. Námietka, podla ktorej z pohl’adu tradičného (dogmatického) marxizmu je každá morálna teória teóriou konzervujúcou status quo podl’a Peffera neobstojí, lebo „[h]oci mnoho morálnych teórií alebo názorov je jasne konzervatívnej povahy v tom, že chránia spoločenský status quo a/alebo záujmy vládnucej triedy $\mathrm{v}$ triednych spoločnostiach, mnoho iných takej povahy nie je“ (s. 257). Inak povedané a zhrnuté, Marxova koncepcia je morálnou teóriou preto, lebo na základe empirických (teda nie normatívnych) poznatkov nemožno rozumne odmietnut' tvrdenie, že Marx vypracoval vlastnú morálnu teóriu. Ked’že nemôžeme empiricky odôvodnit', že Marx vlastnú morálnu teóriu nevypracoval, musíme uznat', že takáto teória $\mathrm{v}$ jeho prípade existuje, prinajmenšom v podobe vol'ne roztrúsených myšlienok.

Druhým bodom originálneho autorského prínosu je pokus o akési „registrované filozofické partnerstvo“ Rawlsovej morálnej teórie s Marxovou koncepciou. Samozrejme, ak pristúpime k obom snahám (prvej snažiacej sa zaradit' Marxa do plejády morálnych teoretikov a tejto druhej) s normatívnou výbavou tradičného (dogmatického) marxistu, oba pokusy sú neplatné aj ako vedecké hypotézy. Normatívna rigidnost' tradičných marxistov však nie je (až na krátky exces v závere) to, čo charakterizuje Pefferov prístup. Ten je, naopak, vel'mi kreatívny a poctivo vychádzajúci z tradície analytickej filozofie. To sa prejavuje v až otrockom dokazovaní a logickom vyvodzovaní záverov z premís, ktoré konfrontuje so svojho času aktuálnymi poznatkami politickej a morálnej 
filozofie. Trvá na tom, že jeho výklad Marxa nie je normatívny, ale empirický. Aj preto pri konfrontácii (vtedy ešte žijúceho) Rawlsa s Marxom nachádza osem empirických podobností oboch teórií, ktoré nesvedčia o tom, že pokus dokázat' podobnosti medzi nimi je bláznivý (pozri s. 358).

Je zjavné, že Pefferove snahy padli aspoň čiastočne na úrodnú pôdu, ked’že sám Rawls jeho teóriu reflektoval a vypracoval neskôr $\mathrm{v}$ „Spravodlivosti ako férovosti“ približné kontúry svojej koncepcie demokracie založenej na vlastníctve (pozri napr. Sekerák 2014), ktorá sa nápadne ponáša na Pefferovu spoločnost’ „demokratického samosprávneho socializmu“. Pre úplnost' treba ale dodat', že Rawls v tejto knihe inkorporoval do istej miery aj komunitaristické námietky, ako napr. ten, že „ukrojil“" zo svojho politického liberalizmu tak, aby nehatil úspešný rozvoj spolkov potvrdzujúcich hodnoty náboženstva a komunity (pozri Rawls 2007: 238-239). Otázkou vo svetle d’alšieho vývoja Rawlsovej teórie teda je, či išlo len o jej rozpracovanie $\mathrm{v}$ duchu filozoficky hodnotných a adekvátnych podnetov, alebo skôr o rezignáciu na obranu pôvodnej teórie spravodlivosti pod t’archou zdrvujúcej kritiky z rôznych strán, predovšetkým zo strany neomarxistov, analytických marxistov a komunitaristov (azda len s výnimkou pravicových libertariánov).

V každom prípade, Pefferovi už nikto nezoberie trvalý odkaz na túto jeho práve recenzovanú knihu $\mathrm{v}$ dvoch Rawlsových monografiách, a to v už spomínanej „Spravodlivosti ako férovosti“ (Rawls 2007: 80, pozn. č. 7) a v „Politickom liberalizme“ (Rawls 1997: 7, pozn. č. 7). Práve v týchto dvoch odkazoch sa vel'ký filozof 20. storočia zaoberá Pefferovými princípmi spravodlivosti, o ktorých bude teraz reč.

Zdá sa, že celé autorovho „otrocké“" snaženie obliect' Marxa do kantovského kabátu a následne ho postavit' povedl'a Rawlsa je zamerané na obhajobu jeho vlastnej teórie sociálnej spravodlivosti, ktorá má smerovat' k socializmu (nie komunizmu, na rozdiel od Marxa), ked’že len ten „možno oprávnene považovat' za skutočnú historickú možnost'“ (s. 312). Táto teória spočíva na štyroch princípoch, ktoré podstatne modifikujú vlastnú Rawlsovu teóriu spravodlivosti, známu v tom čase $\mathrm{z}$ jeho rovnomennej knihy „A Theory of Justice“ (pripomeňme, že „Spravodlivost' ako férovost'“ ešte vtedy nebola publikovaná). Tieto princípy tvoria hlavné jadro jeho knihy, a preto je užitočné ich uviest' vcelku podla lexikálnej priority, akú im Peffer prisudzuje (uvedené princípy sú vymenované na s. 402, kurzíva v orig.):

1. U každého človeka treba rešpektovat' právo na bezpečnost' a existenciu.

2. Musí existovat' systém maximálnej rovnosti základných slobôd, vrátane slobody slova a zhromažd'ovania; slobody svedomia a slobody myslenia; osobnej slobody spolu s právom vlastnit' (osobný) majetok; 
a slobody od svojvolného zatknutia a zhabania majetku, tak ako to definuje pojem vláda zákona.

3. Musí existovat' (a) právo na rovnaké príležitosti pri zastávaní spoločenských pozícií a úradov a (b) rovnaké právo na účast' na všetkých spoločenských rozhodovacích procesoch v rámci inštitúcií, ktorých je daný jednotlivec súčast'ou.

4. Spoločenské a ekonomické nerovnosti sú zdôvodnené vtedy a len vtedy, ked’ prinášajú prospech najmenej zvýhodneným, čo je konzistentné s princípom spravodlivých úspor, nesmú však presiabnut' úroveň, ktorá by vážne podkopala rovnakú hodnotu slobody alebo dobro sebaúcty.

Je tu zjavné, že prioritu autor vo svojom systéme kladie na elementárne ludské potreby zamerané na holé prežitie, aj ked' je hodné poznamenania a rozhodne nie je nezaujímavé upozornit', že v prvom princípe nenachádzame adjektívum „dôstojný/ác v spojení s existenciou. Treba však čestne priznat', že Peffer píše o „minimálnej úrovni blaha“, „pod ktorú l’udia nemôžu spadnút"“ (s. 403). Až po tomto princípe nasleduje lexikálne nižšie situovaný apel na uplatňovanie schémy základných rovných slobôd (teda 1. princíp spravodlivosti u Rawlsa) a právo na férovú rovnost' príležitostí týkajúcu sa verejných postov a úradov (1. čast' Rawlsovho 2. princípu). Druhá čast' Pefferovho 3. princípu je venovaná rovnej účasti na spoločenských rozhodovacích procesoch, teda aj účasti na ekonomickom rozhodovaní, pretože podl'a neho „[d]emokracia nesmie byt' obmedzená na politickú sféru, ale treba ju uplatňovat' aj v spoločenskej a ekonomickej sfére, predovšetkým na pracovisku“ (s. 403). Je zaujímavé a signifikantné zároveň, že práve s touto čast'ou (teda čast'ou 3b) mal Rawls najväčší problém, ked’ o pár rokov reflektoval Pefferov systém princípov spravodlivosti: „Súhlasil by som s väčšinou Pefferových argumentov, nie však s bodom 3(b), ktorý podl'a všetkého vyžaduje socialistickú organizáciu hospodárstva“" (Rawls 1997: 7, pozn. č. 7). Ako už bolo spomenuté, o pár rokov na to Rawls predstavil $\mathrm{v}$ hrubých rysoch vlastný systém trhového socializmu, ktorý chápal ako demokraciu založenú na vlastníctve, a ktorý ponúkol aj v prepracovanej verzii svojej „Teórie spravodlivosti“. Zdá sa teda, že časom sa stotožnil aj s týmto princípom, čo možno (prinajmenšom z pohl’adu jeho kalifornského kolegu) vnímat' ako významný krok. Ako posledný, 4. princíp uvádza napokon Peffer modifikovaný Rawlsov princíp diferencie (ktorý R. Cedzo prekladá niekedy ako ,princíp odlišnosti“: napr. na s. 403 a 408, inokedy už ako „princíp diferencie“: s. 170, v registri pojmov na s. 486).

Polemizovat' zoširoka s Pefferovou schémou teórie spravodlivosti na takomto malom priestore nie je možné. Preto sa obmedzme aspoň na najvypuklejší príklad toho, v čom sa profesor Peffer kruto zmýlil. To sa totiž ukázalo vlastne hned' po vyjdení anglického originálu jeho opus magnum. Ako už 
bolo naznačené vyššie, ako marxista pripúšt’al možnost' primeranej násilnej revolúcie, ak by sa cesta pokojnej evolúcie - inak vždy vhodnejšia a lepšia ukázala ako nemožná z nejakých náležite odôvodnitel’ných príčin, resp. „iba ak nejestvuje nijaká uskutočnitel'ná reformná alternatíva“" (s. 53). Preto navrhol možnost' politických revolúcií $\mathrm{v}$ spoločnostiach štátneho socializmu, kam by bolo v čase do novembra 1989, resp. do slobodných volieb v júni 1990 možné zaradit' napríklad aj Československo. Takéto revolúcie mali podl’a neho za úlohu demokratizovat' politické a ekonomické (!) inštitúcie, pričom by však ponechali v činnosti socializmus ako hospodársky systém, teda by „nezmenili základné výrobné vzt'ahy, a ani nezapríčinili návrat ku kapitalizmu“ (s. 437). Skutočnost', že vývoj sa napokon obrátil iným smerom a došlo k obnoveniu kapitalistického spôsobu výroby, však nutne nefalzifikuje ani Pefferovu teóriu sociálnej spravodlivosti, ani jeho uprednostňovanie demokratického samosprávneho socializmu (Self-Managing Socialism), ktorý Richard Cedzo trochu neobratne prekladá ako „sám seba riadiaci socializmus“.

Tento samosprávny socializmus založený na podnikoch riadených a vlastnených zamestnancami (ekonomická demokracia) pre svoj vznik a zachovanie podla Peffera potrebuje revolúciu, pretože kapitalistický výrobný systém mu nikdy nedovolí rozvinút' sa v rámci neho: „vládnuca kapitalistická trieda - vedomá si svojho vlastného historického záujmu - sa pokúsi zamedzit' rozvoju úspešných podnikov vlastnených a kontrolovaných robotníkmi, ktoré by mohli slúžit' ako výklady socializmu. Vo všeobecnosti bude schopná zabránit' ich rozvoju, lebo takýto podnik bude stále napojený na kapitalistický ekonomický systém ako celok (...)“(s. 219).

Aby sme to zhrnuli, podl’a Peffera: Postkapitalistické spoločnosti (ako napr. Československo) nie sú (a)demokratické, lebo nespíňajú jeho druhý princíp spravodlivosti, (b) ani skutočne socialistické, lebo ich ekonomiky boli (a dodnes v niektorých prípadoch vo väčšej alebo menšej miere sú - napr. v ČL'R, v KL’DR, na Kube, vo Vietname) centrálne plánované, a teda neumožňovali uplatnenie druhej časti tretieho princípu (s výnimkou vtedajšej Juhoslávie s robotníckou samosprávou). Ked’že spoločnosti štátneho socializmu, prípadne postkapitalistické spoločnosti tretieho sveta nezodpovedajú plne jeho teórii spravodlivosti, pričom kapitalistické spoločnosti (s výnimkou napr. Švédska) jej nezodpovedajú vôbec, pretože zlyhávajú v zaist'ovaní prvého princípu pre všetkých svojich obyvatel'ov bez rozdielu príslušnosti $\mathrm{k}$ triede, jedinou reálnou alternatívou sa javí spoločnost' demokratického samosprávneho socializmu, ku ktorej možno dospiet’ reformami, v určitých prípadoch aj revolúciou. Vo väčšine kapitalistických štátov sa táto revolučná cesta javí ako priam nevyhnutná, hoci proletariát podlieha „zburžoázneniu“ pod vplyvom nacionalizmu a/alebo náboženstva, a teda sa nedokáže transformovat' do „triedy pre seba“ (pozri s. 224-227). V prípade tých kapitalistických spoločností, ktoré sa významne približujú k naplńaniu všetkých (alebo takmer všetkých) Pefferových princípov spravodlivosti s nadradeným 
postavením prvého princípu, teda v prípade spoločností, akou je napríklad Švédsko, revolučná možnost' ostáva v hre vtedy a len vtedy, „ked’ nespravodlivosti spoločnosti presiahnu isté hranice“" (s. 421).

$\mathrm{Na}$ záver ešte zhodnot'me Cedzov slovenský preklad. Ten je možno označit' ako vel'mi kvalitný a poctivý, a to aj napriek niekol'kým drobným a zanedbatel'ným preklepom či „slovným zakopnutiam“, ktoré sa prejavili napr. v premenovaní Marxových Ekonomicko-filozofických rukopisov z roku 1844 na „Ekonomické a politické rukopisy“ (s. 30). Podobne došlo k premenovaniu Rawlsovej fundamentálnej práce „A Theory of Justice“ na „A Theory of Social Justice“ (s. 301, pozn. č. 49), čo však nemožno klást' za vinu prekladatel'ovi, ked’že táto chyba sa objavuje už v origináli. Prekladatel’ovo úsilie i odhodlanie vydavatel'a uviest' toto dielo na svetlo nášho slovensko-českého sveta treba teda jednoznačne ocenit', aj ked' užitočnú prácu by okrem autora predhovoru (L'. Blaha) určite mohol vykonat' aj vedecký redaktor (v tiráži o takejto osobe nie je zmienka). Otázkou však je, či preklad do marginálneho slovanského jazyka naozaj pomôže významnejšie šírit’ Pefferove (niekedy viac, inokedy menej originálne) myšlienky, a či odborná verejnost', ktorá má zrejme najväčšie schopnosti recipovat' túto problematiku i fundovaný štýl, akou je predkladaná, nesiahne radšej po anglickej pôvodine.

\section{Bibliografia}

DiQuattro, Arthur (1992): „Marxism, Morality, and Social Justice. By R. G. Peffer (book review).“ The Journal of Politics 54(2): 615-617.

Geoghegan, Vincent (1991): „R.G. Peffer: Marxism, Morality and Social Justice (book note).“ Political Studies 39(2): 438.

Rawls, John (1997): Politický liberalizmus. Prešov: Slovacontact. Preklad: Pavol Štekauer.

Rawls, John (2007): Spravodlivost' ako férovost'. Bratislava: Kalligram. Preklad: Richard Cedzo.

Sekerák, Marián (2014): „Rawlsův model „demokracie založené na vlastnictvi“ jako alternativa k sociálnímu státu?“ Politologická revue 19(2): 113-139. 